\title{
Analisis Asam Lemak Omega-3 dari Minyak Kepala Ikan Sunglir (Elagatis bipinnulata) melalui Esterifikasi Enzimatik
}

\author{
Sri Seno Handayani, Erin Ryantin Gunawan*), Lely Kurniawati, \\ Murniati, dan Lalu Haris Budiarto \\ Program Studi Kimia, Fakultas Matematika dan Ilmu Pengetahuan Alam \\ Universitas Mataram, Jalan Majapahit No. 62, Mataram 83125
}

Diterima 11-12-2012 Disetujui 25-11-2013

\begin{abstract}
Omega-3 fatty acid is the essential fatty acid and important for human health. Omega-3 fatty acid is also really needed by pregnant and lactating mothers and also children to prevent the malnutrition. Omega-3 fatty acid is also really needed by pregnant and lactating mothers, and children to prevent the malnutrition. The omega- 3 fatty acid is commonly found in some fish like salmon, tuna, hering, and mackarel. However, those fish are expensive, so alternative sources relatively cheaper fish. One of fish that is low in price and high in production in Nusa Tenggara Barat is Sunglir (Elagatis bipinnulata). The purpose of this research was to determine free fatty acids content, type of omega-3 fatty acids, and their compositions in head fish oil. Head of sunglir fish was used as a sample because the head was usually not consumed. Sunglir fish was obtained from the Ampenan beach (NTB) with a size of 20-30 cm. The extraction method used in this study was soxhletation with n-hexane solvent and analyzed with Gas Chromatografi (GC), acid ethyl esters from the esterification enzymatic of fish oil. Result revealed that the fish oil contained $84 \%$ free fatty acid and $0.85 \%$ linolenic acid (ALA), 2.80\% eicosatrienoic acid (ETA), $0.73 \%$ eicosapentaenoic acid (EPA) and $2.41 \%$ docosahexaenoic acid (DHA). Saponification and iodine number of head fish oil is $248.24 \mathrm{mg} \mathrm{KOH} / \mathrm{g}$ oil and $227.16 \mathrm{~g} \mathrm{Iod} / 100 \mathrm{~g}$ oil.
\end{abstract}

Keywords: gas chromatography, esterification enzymatic, head of Sunglir Fish (Elagatis bipinnulata), Omega-3 fatty acid

\begin{abstract}
ABSTRAK
Asam lemak omega-3 merupakan asam lemak yang esensial dan penting untuk kesehatan manusia. Asam lemak omega3 sangat dibutuhkan oleh ibu hamil dan menyusui serta balita untuk mencegah gizi buruk. Asam lemak omega-3 banyak dijumpai pada ikan laut seperti salmon, tuna, hering dan makarel. Namun, ikan-ikan ini memiliki nilai ekonomi yang tinggi, untuk tu diperlukan sumber asam lemak omega-3 dari ikan laut yang memiliki harga relatif murah. Salah satu jenis ikan laut yang memiliki harga yang relatif murah produksi yang cukup tinggi di Nusa Tenggara Barat (NTB) adalah ikan Sunglir (Elagatis bipinnulata). Tujuan penelitian ini adalah untuk mendeterminasi kadar asam lemak bebas, jenis asam lemak omega-3, dan untuk mengetahui komposisi masing-masing asam lemak omega-3 yang terdapat pada minyak kepala ikan sunglir. Kepala ikan Sunglir digunakan sebagai sampel karena bagian kepala biasanya tidak dikonsumsi. Sampel ikan Sunglir diperoleh dari pantai Ampenan (NTB) dengan ukuran 20-30 cm. Metode ekstraksi yang digunakan dalam penelitian ini adalah soxhletasi dengan pelarut $n$-heksana, dilanjutkan dengan proses hidrolisis trigliserida. Selanjutnya untuk analisis dengan kromatografi gas digunakan asam lemak etil ester hasil esterifikasi enzimatik minyak
\end{abstract}

\footnotetext{
*Telp: +6281339753767

Email: erinryantin@unram.ac.id
} 
ikan Sunglir. Hasil penelitian menunjukkan bahwa kepala ikan Sunglir mengandung $84 \%$ asam lemak bebas $\pm 0,85 \%$ asam linolenat (ALA), $\pm 2,80 \%$ asam eikosatrienoat (ETA), $\pm 0,73 \%$ asam eikosapentaenoat (EPA), dan $\pm 2,41 \%$ asam dokosaheksaenoat (DHA). Bilangan penyabunan dan bilangan iod dari minyak kepala ikan adalah sebesar 248,24 mg $\mathrm{KOH} / \mathrm{g}$ minyak dan $227,16 \mathrm{~g} \mathrm{Iod} / 100 \mathrm{~g}$ minyak.

Kata Kunci: Asam lemak omega-3, esterifikasi enzimatik, kepala ikan Sunglir, kromatografi gas

\section{PENDAHULUAN}

Masalah gizi masih merupakan masalah utama kesehatan masyarakat di Indonesia. Kekurangan gizi pada umumnya terjadi pada balita karena pada umur tersebut anak sedang mengalami pertumbuhan yang pesat dan masa itu merupakan masa peralihan antara saat disapih dan mulai mengikuti pola makan orang dewasa (Natalia et al. 2013). Berdasarkan angka HUMAN DEVELOPMENT INDEX (HDI), Indonesia menduduki peringkat ke 124 dari 187 negara di dunia (Noviandi 2011). Tidak tertutup kemungkinan peringkat ini akan bergeser ke posisi lebih rendah apabila kondisi ini tidak ditangani secara cepat dan tepat.

Salah satu zat gizi yang perlu untuk dipenuhi oleh masyarakat adalah asam lemak omega-3. Asam lemak ini telah terbukti sangat besar manfaatnya bagi kesehatan karena 1) berperan penting dalam kecerdasan atau perkembangan sel otak dan pertumbuhan; 2) dapat menurunkan kadar kolesterol (hipokolesterolemik); 3) mencegah terjadinya penggumpalan keping-keping darah sehingga menghindari penyumbatan pembuluh darah (arterioklerosis) dan mencegah penyakit jantung; 4) mengurangi resiko penyakit diabetes melitus (kencing manis), hipertensi (tekanan darah tinggi), aneka kanker, penyakit kulit, dan membantu meningkatkan daya tubuh; serta 5) berperan penting dalam proses tumbuh kembang janin (Astawan 2004).

Asam lemak omega-3 banyak dijumpai pada ikan laut seperti ikan salmon, tuna, hering, dan makarel. Kandungan asam lemak omega-3 jenis DHA pada ikan ini sangat tinggi, akan tetapi ikan-ikan ini memiliki nilai ekonomi yang tinggi (Rose \& Connolly 1999). Maka perlu dicari sumber alternatif lain yang murah dan terdapat disekitar kita. Laut NTB kaya akan jenis ikan, sekitar 40 jenis ikan laut, dan salah satu jenis ikan yang memiliki harga yang murah dan tingkat produksi yang cukup tinggi adalah ikan Sunglir (Elagitis bipinnulata).
Produksi ikan ini mencapai 322,31 ton per tahun dengan harga per Kg, sekitar Rp. 16.000,00 (BKP Propinsi NTB 20.).

Ikan Sunglir yang digunakan dalam penelitian ini adalah bagian kepala dari ikan karena biasanya bagian itu tidak pernah dikonsumsi dan bahkan terbuang. Untuk itu perlu diteliti kandungan asam lemak omega-3 dari bagian kepala. Apabila kandungannya cukup signifikan maka bagian kepala ini bisa dijadikan sumber minyak yang kaya akan asam lemak omega-3.

Untuk menganalisis asam lemak omega-3 sebelumnya dilakukan proses ekstraksi minyak kepala ikan Sunglir digunakan metode soxhletasi. Metode soxhletasi dipilih kerena memiliki keunggulan yaitu waktu yang digunakan relatif lebih singkat dan pelarut yang digunakan juga relatif lebih sedikit dibandingkan dengan metode maserasi dan perkolasi, keuntungannya yang lain adalah proses soxhletasi ini berlangsung berkesinambungan (Sarker et al. 2005).

Selanjutnya untuk analisis dengan kromatografi gas digunakan asam lemak etil ester hasil esterifikasi enzimatik minyak ikan Sunglir. Reaksi esterifikasi dilakukan dengan bantuan katalis lipozim (enzim yang sudah diimobilisasi). Keunggulan penggunaan enzim terimobilisasi adalah reaksi dapat lebih tahan terhadap perubahan kondisi seperti $\mathrm{pH}$ dan temperatur serta efisien dan ramah lingkungan.

Penelitian ini bertujuan untuk mendeterminasi kadar asam lemak bebas, jenis asam lemak omega-3, dan untuk mengetahui komposisi masing-masing asam lemak omega-3 yang terdapat pada minyak kepala ikan Sunglir.

\section{BAHAN DAN METODE}

Bahan-bahan yang digunakankan dalam penelitian ini adalah bagian kepala ikan Sunglir dari ikan yang berukuran $20 \times 30 \mathrm{~cm}$, diperoleh dari hasil tangkapan nelayan di pantai Ampenan (NTB). Bagian kepala dicuci 
bersih, dikeringanginkan, dan dilumatkan. Bahan-bahan lainnya yang digunakan adalah $n$-heksana, kertas saring, natrium sulfat anhidrat $\left(\mathrm{Na}_{2} \mathrm{SO}_{4}\right) 96 \%$, pelat KLT, tersier butil hidroquinon (BTHQ), asam lemak omega-3 standar, trigliserida standar, akuades, etanol 96\%, $\mathrm{HCl} 6 \mathrm{~N}$, dan enzim lipase.

Analisis Kadar Air. Dalam analisis kadar air ini, digunakan cawan porselen. Sebelum dilakukan analisis kadar air, cawan porselen terlebih dahulu dikeringkan dalam oven pada suhu $105^{\circ} \mathrm{C}$ selama 15 menit kemudian didinginkan di dalam desikator selama 20 menit. Setelah itu cawan kosong ditimbang, diberi label, dan dicatat. Sampel (daging ikan Sunglir) yang digunakan yaitu masing-masing sebanyak \pm 1 g dengan dua kali pengulangan. Cawan yang telah berisi sampel dioven pada suhu $100-105^{\circ} \mathrm{C}$ selama $3-5$ jam, setelah itu didinginkan dalam desikator kemudian ditimbang. diulangi pemanasan selama 30 menit hingga berat konstan (Sudarmadji 1997).

Analisis Angka Penyabunan. Minyak sebanyak $1 \mathrm{~g}$ dimasukkan ke dalam labu dasar bulat $500 \mathrm{~mL}$ yang dihubungkan dengan pendingin. Kemudian ditambahkan $50 \mathrm{~mL}$ KOH dalam etanol 0,5 $\mathrm{N}$ dan batu didih. Campuran direfluks selama 60 menit. Setelah campuran dingin, ditambahkan lima tetes indikator fenoftalein. Campuran kemudian ditritasi menggunakan larutan $\mathrm{HCl}$ 0,5 $\mathrm{N}$ hingga warna jingga dari indikator hilang. Perlakuan dibuat sama untuk larutan blanko (Sudarmadji et al. 2003).

Analisis Angka Iod. Determinasi angka iod dilakukan menurut prosedur Hanus. Sebanyak $2 \mathrm{~g}$ minyak dimasukkan ke dalam labu alas bulat yang dihubungkan dengan pendingin. Ditambahkan $15 \mathrm{~mL} \mathrm{CCl}_{4}$ untuk melarutkan minyak dan $25 \mathrm{~mL}$ larutan Hanus (10 g Iodine monobromida dalam $500 \mathrm{~mL}$ asam asetat), aduk hingga bercampur semua. Campuran dibiarkan di tempat gelap selama 60 menit. Setelah itu ditambahkan $20 \mathrm{~mL}$ larutan KI 15\% dan ditambahkan $100 \mathrm{~mL}$ akuades yang telah dididihkan, dan segera dititrasi dengan larutan $\mathrm{Na}_{2} \mathrm{~S}_{2} \mathrm{O}_{3}$ 0,1 N sampai larutan berwarna kuning pucat, kemudian ditambahkan $4 \mathrm{~mL}$ larutan kanji. Titrasi dilanjutkan sampai warna biru tepat hilang setelah diaduk.

Larutan blanko dibuat dari $25 \mathrm{~mL}$ larutan Hanus dan dibiarkan di tempat gelap selama 60 menit. Setelah itu ditambahkan $20 \mathrm{~mL}$ larutan KI 15\% dan ditambahkan $100 \mathrm{~mL}$ akuades yang telah dididihkan, dan segera dititrasi dengan larutan $\mathrm{Na}_{2} \mathrm{~S}_{2} \mathrm{O}_{3} 0,1 \mathrm{~N}$ sampai larutan berwarna kuning pucat, kemudian ditambahkan $4 \mathrm{~mL}$ larutan kanji. Titrasi dilanjutkan sampai warna biru tepat hilang setelah diaduk. Banyaknya $\mathrm{Na}_{2} \mathrm{~S}_{2} \mathrm{O}_{3}$ untuk titrasi blanko dikurangi titrasi yang sesungguhnya adalah ekivalen dengan banyaknya iodium yang diikat oleh lemak atau minyak (Sudarmadji et al. 2003).

Ekstraksi dan Uji Kualitatif dengan KLT. Daging ikan yang sudah dihaluskan ditimbang dan dimasukkan ke dalam timbel Soxhlet kemudian dialiri air. Ekstraksi dilakukan selama \pm 6 jam diatas penangas air. Pelarut yang digunakan adalah $n$-heksana. Hasil ekstraksi dikeringkan dengan natrium sulfat anhidrat. Setelah tidak mengandung air, hasil ekstraksi diuapkan untuk menghilangkan $n$-heksana dengan evaporator pada suhu $40^{\circ} \mathrm{C}$.

Hidrolisis Trigliserida. Sebanyak $1 \mathrm{~g}$ minyak hasil ekstraksi ditambahkan BTHQ 200 ppm, kemudian disaponifikasi dengan menambahkan 0,32 g larutan $\mathrm{KOH}$ dalam alkohol encer (air dan etanol 96\% $60 \mathrm{~mL}(1: 1)$ ). Reaksi dilakukan pada suhu $60^{\circ} \mathrm{C}$ selama 1 jam. Minyak yang telah disabunkan ditambahkan $50 \mathrm{~mL}$ akuades dan diekstrak dengan $n$-heksana $200 \mathrm{~mL}$ menggunakan corong pisah sampai terbentuk dua lapisan. Didapatkan 2 fraksi yaitu fraksi air yang tersaponifikasi dan fraksi $n$-heksana yang tidak tersaponifikasi. Fraksi air (tersaponifikasi) diasamkan dengan menambahkan $\mathrm{HCl}$ $6 \mathrm{~N}$ beberapa tetes sampai $\mathrm{pH}$ nya 1 dan diekstrak kembali dengan $n$-heksana $200 \mathrm{~mL}$. Hasil ekstraksi didapatkan dua fraksi yaitu fraksi air dan fraksi $n$-heksana yang mengandung asam lemak bebas. Setelah itu fraksi $n$-heksana ditambahkan natrium sulfat anhidrat dan diuapkan.

Proses Esterifikasi. Asam lemak yang telah didapatkan diubah menjadi etil ester dengan menambahkan etanol 95\% dengan rasio 1:1. Setelah itu ditambahkan 0,15 g enzim lipase dan $10 \mathrm{~mL} n$-heksana. Kemudian diletakkan di dalam water bath shaker selama 24 jam pada suhu $45^{\circ} \mathrm{C}$ dan kecepatan $150 \mathrm{rpm}$. Setelah itu dilakukan analisis menggunakan alat GC. Kondisi alat GC adalah sebagai berikut: suhu injektor $280{ }^{\circ} \mathrm{C}$ dan 
detektor $320^{\circ} \mathrm{C}$. Suhu terprogram $200^{\circ} \mathrm{C}$ naik $10^{\circ} \mathrm{C} / \mathrm{min}$ sampai $300^{\circ} \mathrm{C}$. Helium sebagai carrier gas.

\section{HASIL DAN PEMBAHASAN}

Penentuan Kadar Air. Kadar air dari kepala ikan Sunglir adalah 64,16\%. Dari penelitian sebelumnya jika dibandingkan dengan badan ikan Sunglir ternyata ratarata kadar air kepala ikan Sunglir lebih kecil dibandingkan badan ikan Sunglir (78,33\%) (Budiarto 2011). Menurut Sudarmadji et al. (2003) bahwa kadar air yang tinggi dalam bahan dapat menyebabkan minyak atau lemak sukar diekstraksi dengan pelarut nonpolar karena bahan pelarut sukar masuk ke dalam jaringan yang basah dan menyebabkan bahan pelarut menjadi jenuh dengan air sehingga kurang efisien untuk ekstraksi. Selain itu, kandungan air dalam bahan pangan dapat mempercepat proses oksidasi. Pada ikan biasanya kandungan air ditambah lemak sama dengan $80 \%$, dan apabila kadar airnya semakin tinggi maka kadar lemak semakin rendah. Kadar air kepala ikan Sunglir hampir mirip dengan kadar air kepala ikan lele $(60,05 \%)$ (Gunawan et al. 2014) tetapi lebih rendah dari kepala ikan belut $(71,66 \%)$ (Margawati 2014), dan ikan layang (79,13\%) (Kurniawati et al. 2013). Perbedaan kadar air ini dapat dipengaruhi oleh beberapa faktor antara lain: lokasi, musim, pertumbuhan, dan jenis makanannya (Fitriani 2006) dan struktur kepalanya.

Ekstraksi Minyak Ikan Sunglir. Minyak atau trigliserida memiliki kepolaran yang terletak pada gugus esternya yang tersusun atas gugus karbonil dan karboksilnya tetapi secara umum molekul minyak nabati bersifat nonpolar, karena kepolaran gugus esternya tertutupi oleh panjangnya rantai karbon yang membentuk molekul trigliserida yang bersifat nonpolar. Sehingga untuk dapat melarutkannya digunakan pelarut yang bersifat nonpolar, sesuai dengan prinsip "like dissolves like" yaitu senyawa akan mudah larut dengan polaritas yang sama (Nilasari 2004), karena itu pelarut yang digunakan untuk mengekstrak minyak pada ikan Sunglir yaitu $n$-heksana yang bersifat nonpolar.

Kadar minyak pada kepala adalah 1,54\%. Kadar minyak ini lebih tinggi Jika dibandingkan dengan badan ikan Sunglir (0,32\%.) (Budiarto 2011). Perbedaan kadar minyak mungkin pengaruhi oleh perbedaan kadar air pada kepala dan badan ikan Sunglir. Kepala ikan Sunglir mempunyai kadar minyak ikan lebih tinggi jika dibandingkan kepala ikan tongkol (1,19\%) (Ripsanim 2011) tetapi lebih rendah dari ikan layang (2\%) (Kurniawati et al. 2013). Semakin tinggi kadar air dalam bahan makanan menyebabkan minyak atau lemak sukar diekstraksi dengan pelarut nonpolar karena bahan pelarut sukar masuk ke dalam jaringan yang basah dan menyebabkan bahan pelarut menjadi jenuh dengan air sehingga kurang efesien untuk ekstraksi (Fitriani 2006).

Minyak yang diperoleh harus disimpan dalam kondisi yang baik karena minyak sangat mudah teroksidasi. Apabila minyak dibiarkan lama di udara terbuka, akan menimbulkan rasa dan bau yang tidak enak. Hal ini disebabkan oleh proses hidrolisis yang menghasilkan asam lemak bebas. Disamping itu, dapat pula terjadi proses oksidasi terhadap asam lemak tidak jenuh yang menghasilkan peroksida. Kelembapan udara, cahaya, suhu tinggi, dan adanya bakteri perusak merupakan faktor penyebab terjadinya ketengikkan lemak. Ketengikkan minyak ini dapat menurunkan mutu dan nilai gizinya (Poejiadi \& Supriyanti 2007).

Penentuan Bilangan Penyabunan dan Bilangan Iod. Bilangan penyabunan dari minyak kepala ikan Sunglir adalah 248,24 mg KOH/g minyak. Bilangan penyabunan dapat digunakan untuk menentukan berat molekul minyak dan lemak secara kasar. Minyak yang disusun oleh asam lemak berantai $\mathrm{C}$ pendek berarti mempunyai berat molekul relatif kecil akan mempunyai bilangan penyabunan yang besar dan sebaliknya minyak dengan berat molekul besar mempunyai angka penyabunan relatif kecil (Ketaren 1986).

Dari hasil penelitian yang telah dilakukan oleh Ripsanim (2011) dan Kurniawati et al. (2013) bilangan penyabunan dari minyak kepala ikan tongkol sebesar 218,025 dan kepala ikan layang sebesar 201,96 mg KOH/g minyak. Jika dibandingkan dengan kedua kepala ikan tersebut, bilangan penyabunan minyak kepala ikan Sunglir mempunyai nilai yang lebih besar. Perbedaan bilangan penyabunan ini kemungkinan karena pada minyak kepala ikan Sunglir mempunyai asam 
lemak penyusunnya memiliki rantai $\mathrm{C}$ yang lebih pendek dibanding dengan rantai $\mathrm{C}$ dari asam lemak penyusun minyak ikan layang dan tongkol.

Penentuan bilangan iod dalam penelitian ini bertujuan untuk mengetahui banyaknya ikatan rangkap yang terkandung dalam minyak ikan Sunglir. Angka iod tinggi menunjukkan bahwa minyak tersebut mengandung asam lemak yang mempunyai banyak ikatan rangkap. Ikatan rangkap yang terdapat dalam asam lemak yang tidak jenuh akan bereaksi dengan iod atau senyawasenyawa iod. Minyak yang mengandung asam lemak dengan ketidakjenuhan tinggi, akan mengikat iod dalam jumlah yang lebih besar (Ketaren 1986). Dari hasil penelitian diperoleh bilangan iod dalam minyak ikan Sunglir adalah 227,16 g Iod/100 g minyak. Nilai bilangan iod minyak kepala ikan Sunglir lebih tinggi dari minyak kepala ikan tongkol $(211,94)$ (Ripsanim 2011) tetapi lebih rendah dari nilai bilangan iod ikan layang $(243,667)$ (Kurniawati et al. 2014).

Analisis Asam Lemak Bebas. Tabel 1. Memperlihatkan data kadar air, kadar minyak, dan asam lemak bebas dari bagian kepala ikan Sunglir. Dari data diatas dapat dilihat berat asam lemak bebas dari minyak kepala ikan Sunglir adalah $84 \%$. Jauh lebih tinggi dari kandunagan asam lemak bebas bagian badan ikan Sunglir (38\%) (Budiarto 2011). Diharapkan asam lemak bebas dari bagian kepala ini lebih banyak mengandung asam lemak bebas tak jenuh. Salah satu kelebihan dari asam lemak ikan adalah mengandung asam lemak tak jenuh yang relatif banyak daripada asam lemak jenuhnya. Lemak ikan pada umumnya mengandung $75 \%$ asam lemak tak jenuh dan $25 \%$ asam lemak jenuh (Sukarsa 2004).

Pada proses hidrolisis dilakukan pemanasan pada suhu $\pm 60^{\circ} \mathrm{C}$ sehingga minyak rentan teroksidasi, untuk mencegahnya ditambahkan antioksidan yaitu TBHQ

Tabel 1 Data kadar air, kadar minyak dan asam lemak bebas, asam lemak etil ester bagian kepala ikan Sunglir

\begin{tabular}{lc}
\hline \multicolumn{1}{c}{ Jenis } & Persentase $(\%)$ \\
\hline Kadar air & 64,16 \\
Kadar minyak & 1,54 \\
Asam lemak bebas & 84 \\
Asam lemak etil ester & 60,71 \\
\hline
\end{tabular}

(Tertiary butyl hydroquinone), yang di dalam proses ini berfungsi agar ikatan rangkap pada rantai alkil asam lemak yang diharapkan berupa asam lemak tak jenuh tidak berubah menjadi ikatan tunggal. TBHQ merupakan turunan hidrokuinon yang berfungsi sebagai antioksidan sintetik yang dapat menghambat terjadinya autooksidasi pada lemak tak jenuh. Autooksidasi merupakan pembentukan radikal-radikal bebas yang disebabkan oleh faktor-faktor yang dapat mempercepat reaksi seperti panas, cahaya, peroksida lemak, hidroperoksida, logamlogam berat seperti $\mathrm{Cu}, \mathrm{Fe}, \mathrm{Co}$, dan $\mathrm{Mn}$, logam porfirin seperti hemoglobin. Proses oksidasi pada minyak dapat menyebabkan terjadinya ketengikan sehingga dapat merusak mutu minyak. Adanya antioksidan dalam minyak akan mengurangi kecepatan oksidasi. Antioksidan sintetik ini berfungsi sebagai donor yang diperlukan membentuk hiperoksida. Molekul antioksidan akan teroksidasi, tapi radikal bebas tidak terbentuk (Winarni 2001).

Pada proses hidrolisis didapatkan dua lapisan yaitu fraksi air dan fraksi heksan. Fraksi $n$-heksana yang tak tersaponifikasi berada dilapisan bawah sedangkan lapisan air yang tersaponifikasi berada pada lapisan atas. Fraksi tersaponifikasi adalah garam asam lemak (sabun) dan gliserol, dimana asam lemak apabila ditambahkan dengan air akan terbentuk sabun. Asam lemak bila dalam larutan $\mathrm{KOH}$ akan berada dalam keadaan terionisasi sehingga menjadi lebih polar dari aslinya sehingga dapat terekstrak oleh air. Untuk mendapatkan asam lemak bebas, garam asam lemak diasamkan menggunakan larutan $\mathrm{HCl}$ kemudian ditambahkan pelarut $n$-heksana untuk memisahkan gliserol dari asam lemak. Gliserol yang didapatkan dari hasil penyabunan minyak adalah suatu zat cair yang tidak berwarna dan terlarut dengan baik dalam air (Poejiadi 2007), oleh karena itu asam lemak akan didapatkan dalam fraksi $n$-heksana sedangkan gliserol terpisah ke dalam fraksi air.

Esterifikasi Asam Lemak. Proses untuk mendapatkan Fatty Acid Ethyl Ester (FAEE) atau etil ester asam lemak, dapat dilakukan dengan cara esterifikasi dengan katalis basa, asam atau dengan penggunaan enzim (Rachmaniah 2006). Esterifikasi dilakukan karena asam lemak sulit dianalisis dengan kromatografi gas. 
Senyawa yang tidak stabil secara termal ataupun tidak mudah menguap seperti asam lemak dapat dianalisis dengan kromatografi gas, dengan cara mengubahnya menjadi turunan-turunannya yang lebih mudah menguap dan stabil (Fitriani 2006). Dalam penelitian ini proses esterifikasi dilakukan dengan menggunakan enzim. Enzim yang digunakan sebagai katalis dalam penelitian ini adalah enzim lipase yang sudah diimobilisasi (Lipozim). Lipase yaitu enzim yang biasa digunakan sebagai biokatalis pada proses pengolahan minyak nabati yang dapat diisolasi dari tumbuhan. Keuntungan dari pengggunaan enzim yang sudah diimobilisasi selain enzim tersebut lebih stabil, enzim dapat digunakan kembali (reusability) karena mudah dipisahkan dari pereaksinya. Adapun kelebihan lain dari proses esterifikasi secara enzimatis antara lain reaksi yang dapat berlangsung pada suhu rendah, sehingga hasil yang didapatkan lebih bagus dan dengan menggunakan enzim yang lipase yang spesifik, produk yang diinginkan dapat ditingkatkan, sedangkan produk samping dapat dikurangi. Adapun proses esterifikasi ini berlangsung selama 24 jam dalam water bath shaker dengan suhu $40^{\circ} \mathrm{C}$ dengan kecepatan $150 \mathrm{rpm}$. Pada umumnya setiap kenaikan $10^{\circ} \mathrm{C}$, kecepatan reaksi dapat meningkat menjadi 2 atau 3 kali lipat, tetapi pada suhu di atas $50^{\circ} \mathrm{C}$, umumnya enzim sudah mengalami kerusakan (Tambun 2002).

Dari reaksi esterifikasi ini, terlihat bahwa produk samping yang dihasilkan adalah air. Untuk menghilangkan air yang dihasilkan maka ditambahkan natrium sulfat anhidrat yang selanjutnya dipisahkan dengan cara dekantasi. Adanya produk samping yang dihasilkan pada proses ini maka asam lemak etil ester yang didapatkan tidak mencapai 100\% dari asam lemak bebasnya seperti yang tertera pada Tabel 1 .

Dari data tersebut dapat dilihat asam lemak etil ester fatty acid etil ester (FAEE) hasil esterifikasi asam lemak dari kepala ikan Sunglir lebih besar bila dibandingkan dengan asam lemak etil ester dari badan ikan Sunglir. Ada empat faktor yang mempengaruhi reaksi esterifikasi yaitu waktu reaksi, pengadukan, katalisator, dan suhu reaksi (Nurhayati 2009). Semakin lama waktu reaksi maka kontak antara zat semakin besar sehingga reaktan yang dihasilkan semakin maksimal, namun jika kesetimbangan reaksi telah tercapai maka meskipun dengan penambahan waktu tidak akan memperbesar hasil konversi. Untuk itu pada penelitian ini digunakan waktu reaksi selama 24 jam agar mendapatkan konversi yang maksimal karena pada penelitian tidak ditentukan waktu optimum dari proses esterifikasi.

Analisis Asam Lemak Etil Ester. Untuk analisis asam lemak etil ester kepala dan badan ikan Sunglir, asam lemak etil ester yang digunakan adalah asam lemak etil ester dari proses transesterifikasi minyak ikan Sunglir. Analisis asam lemak dilakukan dengan menggunakan instrumen kromatografi gas spektrometri massa. Untuk mengetahui jenis omega-3 yang terkandung dalam sampel asam lemak metil ester digunakan standar asam lemak omega-3 antara lain ALA, ETA, EPA, dan DHA dengan masing-masing atom karbon berjumlah 20, 20, dan 22.

Prinsip pemisahan pada kromatografi gas yaitu senyawa yang memiliki titik didih yang lebih tinggi dari temperatur kolom cenderung akan berkondensasi pada awal kolom. Sehingga yang pertama kali dibaca adalah asam lemak dengan jumlah atom $\mathrm{C}$ lebih sedikit yang kemudian diikuti dengan jumlah atom $\mathrm{C}$ yang lebih banyak dan apabila memiliki ikatan rangkap maka asam lemak dengan sedikit ikatan rangkap akan keluar terlebih dahulu (Sudarmadji 1997). Untuk itu dari kromatogram hasil analisis standar asam lemak omega-3 didapatkan empat puncak puncak yang teridentifikasi yaitu ALA, ETA, EPA, dan DHA yang secara berurutan dengan

Tabel 2 Data perbandingan waktu retensi standar dan sampel asam lemak omega-3 kepala ikan Sunglir

\begin{tabular}{llc}
\hline \multicolumn{1}{c}{ Asam lemak Omega-3 } & \multicolumn{2}{c}{ Waktu retensi (menit) } \\
\cline { 2 - 3 } \multicolumn{1}{c}{ Etil linolenat } & Standar & Sampel \\
Etil eikosatrienoat & 24,280 & 24,188 \\
Etil eikosapentaenoat & 27,742 & 27,919 \\
Etil dokosaheksaenoat & 28,31 & 28,680 \\
\hline
\end{tabular}


waktu retensi yang berbeda. Waktu retensi adalah waktu yang dibutuhkan oleh suatu senyawa untuk bergerak melalui kolom menuju detektor. Setiap senyawa memilki waktu retensi yang berbeda, waktu retensi dipengaruhi oleh temperatur kolom, titik didih senyawa, dan kelarutan dalam fase cair. Senyawa yang memiliki titik didih yang tinggi akan memiiki waktu retensi yang lama dan sebaliknya senyawa yang memiliki titik didih yang rendah akan memiliki waktu retensi yang cepat, hal ini terjadi karena suhu pada kolom diawali dengan suhu rendah yang secara bertahap akan semakin panas yang mengakibatkan senyawa dengan titik didih tinggi akan mengalami kondensasi yang lebih lama. Untuk menentukan asam lemak omega-3 apa saja yang terkandung dalam sampel, dapat dilakukan dengan membandingkan waktu retensi sampel dengan standar asam lemak omega-3 yang terdapat dalam range standar yaitu pada kisaran menit ke-20 sampai menit ke-35.

Pada kromatogram asam lemak etil ester kepala ikan sunglir terlihat cukup banyak puncak, namun yang harus diperhatikan adalah puncak dengan waktu retensi pada jarak puncak standar. Dari pencocokan waktu retensi terdapat 4 puncak yang memiliki waktu retensi yang mendekati standar, yang dapat dilihat pada Tabel 3 .

Dari tabel tersebut dapat dilihat terdapat empat puncak yang memiliki waktu retensi yang hampir mendekati standar yaitu pada puncak ke-12 dengan waktu retensi 24,188 yang hampir sama dengan waktu retensi dari asam linolenat (ALA), puncak ke-15 dengan waktu retensi 27,919 yang hampir sama dengan waktu retensi asam eikosatrienoat (ETA), puncak ke-16 dengan waktu retensi 28,680 hampir sama dengan waktu retensi dari asam eukosapentaenoat (EPA) dan puncak ke-19 dengan waktu retensi 33,586 yang hampir mirip dengan waktu retensi asam dokosaheksaenoat (DHA) (Gambar 2).

Dari hasil pendekatan tersebut menunjukkan asam lemak omega-3 yang terkandung dalam minyak kepala ikan Sunglir (Elagatis bipinnulata) adalah ALA, ETA, EPA, dan DHA dengan persen komposisi masing-masing adalah $0,85 \%, 2,80 \%, 0,73 \%$, dan $2,41 \%$. Total asam lemak omega-3 pada bagian kepala ikan Sunglir adalah 6,79\%.

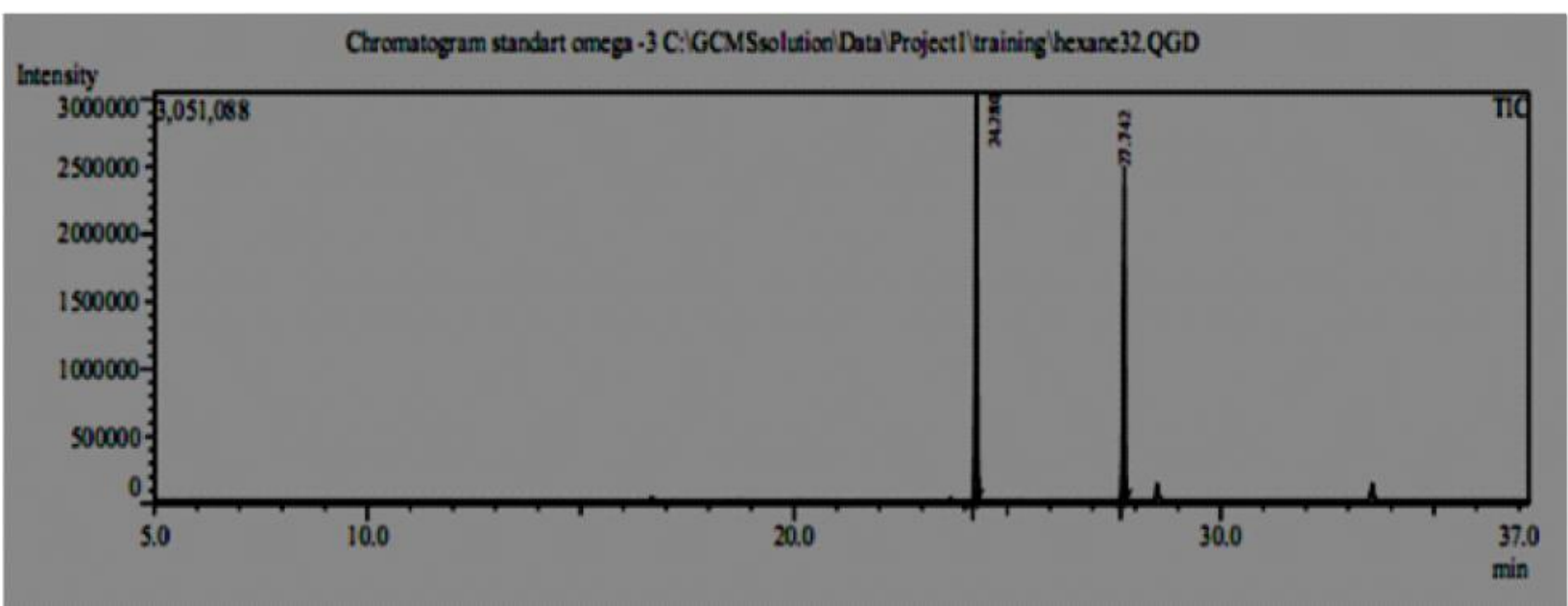

Gambar 1 Kromatogram standar asam lemak omega-3 $\left(\mathrm{R}_{\mathrm{f}}\right.$ Puncak $1=24,280, \mathrm{R}_{\mathrm{f}}$ puncak $2=27,742, \mathrm{R}_{\mathrm{f}}$ puncak $3=28,31$, dan $\mathrm{R}_{\mathrm{f}}$ puncak $4=33,42$ )

Tabel 3 Tabel kandungan dan komposisi asam lemak omega-3 kepala ikan Sunglir

\begin{tabular}{lcc}
\hline \multicolumn{1}{c}{ Jenis asam } & $\begin{array}{c}\text { Kandungan asam lemak omega-3 dalam } \\
\text { kepala ikan Sunglir } \\
(\mathrm{mg} / 100 \mathrm{~g})\end{array}$ & $\begin{array}{c}\text { Komposisi asam lemak omega-3 } \\
(\%)\end{array}$ \\
Asam linolenat (ALA) & 13,098 & 0,85 \\
Asam eikosatrienoat (ETA) & 43 & 2,80 \\
Asam eikosapentaenoat (EPA) & 11,25 & 0,73 \\
Asam dokosaheksaenoa (DHA) & 37,14 & 2,41 \\
\hline
\end{tabular}




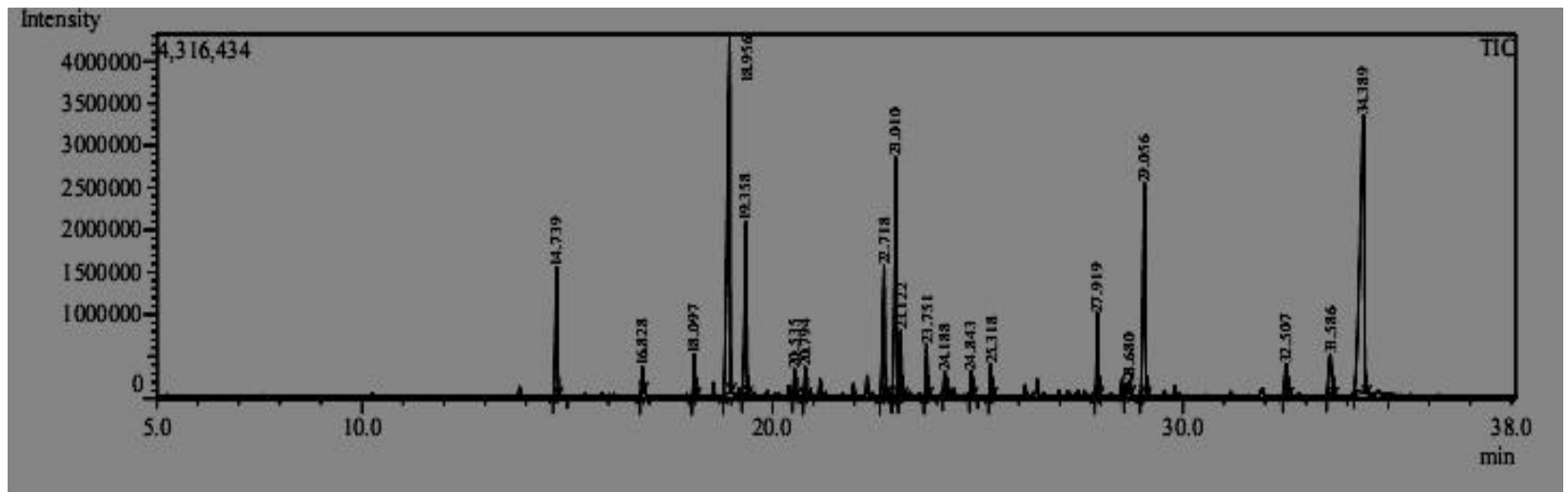

Gambar 2 Kromatogram asam lemak etil ester kepala ikan Sunglir $\left(R_{f}\right.$ puncak $12=24,188, R_{f}$ puncak $15=27,919, R_{f}$ puncak $16=28,680$, dan $R_{f}$ puncak $\left.19=33,586\right)$

Hasil ini hampir mirip dengan kandungan asam lemak omega-3 pada ikan bawal $(9,15 \%)$ (Sukarsa 2004) tetapi masih lebih kecil daripada kandungan kepala ikan layang $(25,07 \%)$ (Kurniawati et al. 2014). Perbedaan kandungan EPA dan DHA pada ikan sunglir dan ikan bawal sangat dimungkinkan karena komposisi lemak dan asam lemak pada ikan sangat tergantung pada spesies, habitat, dan jenis makanan (Sukarsa 2004).

Dari keseluruhan hasil analisis asam lemak omega-3 dapat ditentukan kandungan asam linolenat (ALA), asam eikosatrienoat (ETA), asam eikosapentaenoat (EPA), dan dokosaheksaenoat (DHA) dalam $100 \mathrm{~g}$ daging kepala ikan Sunglir masing adalah $13,098 \mathrm{mg}, 43 \mathrm{mg}, 11,25 \mathrm{mg}$, dan 37,14 mg.

\section{SIMPULAN}

Pada bagian kepala ikan Sunglir terkandung empat jenis asam lemak omega-3 yaitu asam linolenat (ALA), Eikosatrienoat (ETA), Eikosapentaenoat (EPA), dan Dokosaheksaenoat (DHA). Persentase komposisi asam linolenat (ALA), Eikosatrienoat (ETA), Eikosapentaenoat (EPA), dan Dokosaheksaenoat (DHA) masing-masing adalah 0,$85 ; 2,80 ; 0,73$; dan $2,41 \%$. Sehingga bagian kepala ikan Sunglir yang biasanya tidak dimanfaatkan dapat dijadikan sebagai salah satu sumber alternatif asam lemak omega-3.

\section{DAFTAR PUSTAKA}

Astawan, M. 2004. Ikan yang sedap dan bergizi. Solo: Tiga Serangkai Pustaka Mandiri.
Budisrto, H. 2011. Analisis asam lemak omega-3 dari minyak badan ikan Sunglir (Elagatis bipinnulata), Skripsi. Mataram: Universitas Mataram.

Fitriani, A. 2006. Profil asam lemak omega-3 dalam hati ikan manyung (Arius thalassinus) yang mengalami pemanasan pendahuluan (Blanching). Thesis. Semarang: Universitas Diponegoro.

Gunawan, E.R., Basri, M., Rahman, M.B.A., Rahman, R.N.Z.A \& SallehA.B. 2005. Study on response surface methodology (RSM) of lipase-catalyzed synthesis of palm-based wax ester. Enzyme and Microbial Technology Journal 37(7): 739-744.

Gunawan \& Suhendra. 2012. Screening dan analisis kadar omega-3 dari rumput laut pulau Lombok. Jurnal Molekul 7(2): 95-104.

Gunawan, E.R., Suhendra, D., Handayani, S.S., Kurniawati, L., Murniati \& Nurhidayanti. 2014. Analisis Kandungan Asam Lemak Omega-3 Dan 6 Pada Bagian Kepala Dan Badan Ikan Lele (Clarias Sp) Melalui Reaksi Enzimatis. Prosiding Seminar Nasional Kimia: Peningkatan Sumber Daya Manusia dan sumber Daya Alam dalam Pendidikan Kimia dan Kimia untuk Kemandirian Bangsa. FMIPA Unesa, Surabaya, 20 September 2014.

Noviardi, A. 2011. Kualitas hidup manusia indonesia di peringkat ke-124 dunia http://datakesra.menko kesra.go.id com. (20 September 2013).

Ketaren, S. 1986. Minyak dan lemak pangan. Jakarta: UI Press.

Kurniawati, L., Gunawan, E.R., Handayani, S.S., Murniati \& Maknun, S.L. 2013. Analisis kandungan omega-3 dalam ekstrak minyak ikan melalui esterifikasi enzimatik. Prosiding Seminar Nasional; Penelitian, Pembelajaran Sains dan Implmentasi Kurikulum 2013, Program Studi Magister IPA, Universitas Mataram, 7 Desember 2013. 
Natalia, Destri, L., Rahayuning, D \& Fatimah, S. 2013. Hubungan ketahanan pangan tingkat keluarga dan tingkat kecukupan zat gizi dengan status gizi batita di desa gondang winangun tahun 2012. Jurnal Kesehatan Masyarakat 2(2): 1-19.

Poejiadi, A \& Supriyanti, F.M.T. 2007. Dasar-Dasar Biokimia, Jakarta: UIP.

Rachmaniah, O. 2006. Studi transesterifikasi berkatalis asam triglycerida dan fatty acid dari minyak mentah dedak padi menjadi biodiesel. Thesis. Surabaya: ITS.

Rasyid, A. 2003. Asam lemak omega-3 dari minyak ikan. Osceana XXVIII (3): 11-16.

Rose, D.P. \& Connolly, J.M. 1999. Omega-3 fatty acids as cancer chemopreventive agents. Pharmacology \& Therapeutics 83(3): 217-244.

Ripsanim. 2011. Analisis kandungan omega-3 dalam ekstrak minyak ikan tongkol. Skripsi. Mataram: Universitas Mataram.
Sarker, S.D., Ltif, Z \& Gray, I. 2005. Natural Products Isolation (2nd ed.). Totowa, NJ: Humana Press.

Sudarmadji, S. 1997. Prosedur Analisa Untuk Bahan Makanan dan Pertanian. Yogyakarta: Liberty.

Sudarmadji, Slamet, Bambang, H \& Suhadi. 2003. Analisa Bahan Makanan dan Pertanian. Yogyakarta: Liberty.

Sudjadi. 1998. Metode Pemisahan. Yogyakarta: Kanisius.

Sukarsa. 2004. Studi aktifitas asam lemak omega-3 ikan laut pada mencit sebagai model hewan percobaan. Bandung: Buletin Teknologi Hasil Perikanan 7(1): 68-77.

Tambun, R. 2002. Proses pembuatan asam lemak secara langsung dari buah kelapa sawit. Thesis. Medan: Universitas Sumatera Utara, USU digital library.

Winarni. 2001. Efektifitas vitamin E dan BHT sebagai penghambat oksidasi asam lemak omega-3 jenis EPA dan DHA pada daging ikan manyung (Arius thalassinus). Thesis. Yogyakarta: FMIPA UGM. 